\title{
Cervicothoracic 'no man's land': an unusual location of intravascular papillary endothelial hyperplasia in the supraclavicular fossa presenting a surgical challenge
}

\author{
Catriona Shenton (1) , Safdar Sarwar, Jay Goswamy
}

Otorhinolaryngology, Manchester University NHS Foundation Trust, Manchester, UK

\section{Correspondence to} Dr Catriona Shenton; trioshenton@gmail.com

Accepted 8 February 2021

\section{DESCRIPTION}

A 45-year-old woman presented with an asymptomatic left supraclavicular lump after noticing shoulder asymmetry. Ultrasound revealed a well-circumscribed heterogenous, principally hypoechoic mass measuring $41 \times 23 \times 32 \mathrm{~mm}$. This mass appeared to arise in the fat in the supraclavicular fossa, displacing adjacent muscles. Doppler showed vascularity within the mass. Incisional biopsy identified a non-lipomatous, reasonably well-circumscribed, intensely vascular lesion with deep extension into the left supraclavicular fossa. Histology was reported as skeletal muscle, with an adjacent thrombosed vessel with intravascular papillary endothelial hyperplasia. There was no evidence of neoplasia. MRI demonstrated a wellcircumscribed mixed-signal mass in the left supraclavicular fossa, measuring $56 \times 40 \times 40 \mathrm{~mm}$. This mass lay deep to the levator scapulae muscle and posterior to the left supraclavicular artery and vein, extending caudally to the level of the second rib and displacing adjacent structures.

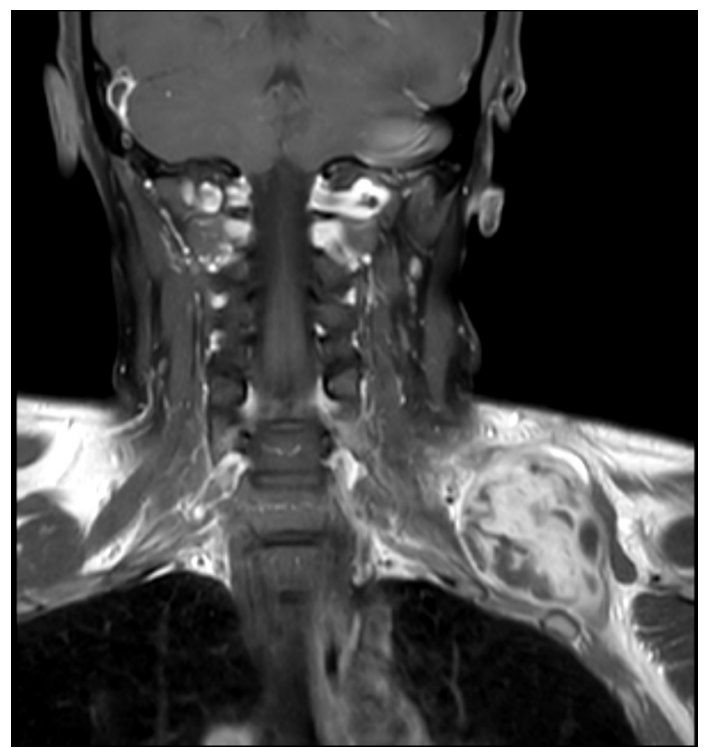

Limited 2021. No commercial re-use. See rights and permissions. Published by BMJ.

To cite: Shenton C, Sarwar S, Goswamy J. BMJ Case Rep 2021;14:e240479. doi:10.1136/bcr-2020240479

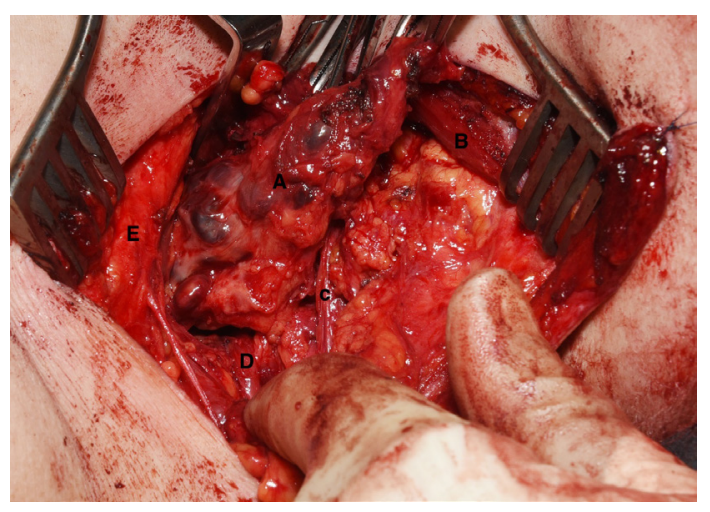

Figure 2 Intraoperative photograph of the mass in the left supraclavicular fossa. A-Mass (intravascular papillary endothelial hyperplasia); B-scalene muscle; C—scalene muscle; D—brachial plexus; E-clavicle.

On repeat MRI at 6 months, the mass measured $54 \times 43 \times 51 \mathrm{~mm}$ (figure 1 ). Surgical removal was attempted by otolaryngology but was unsuccessful due to the location of the mass and proximity to surrounding structures.

Multidisciplinary team (MDT) review of images to determine the most appropriate management options concluded the presence of a smoothly marginated $43 \times 56 \times 49 \mathrm{~mm}$ spindle-like lesion in the left supraclavicular fossa, lateral to the scaleni muscles and posterior to the vasa subclavia. Numerous small vessels were suggested, with no direct contact with the subclavian vessels. Possible contact with the brachial plexus was seen. There was a suggested 'neck' in its inferior part towards the left serratus anterior muscle, from which the lesion appeared inseparable.

The location of this neck lump therefore provided a challenge to its surgical management, with consultation including tertiary level otolaryngology, cardiothoracic surgery and plastic surgery indicated for its supraclavicular fossa location, caudal extension to the second rib and proximity to the brachial plexus, respectively. Consultations occurred with secondary level otolaryngology, regional plastic surgery and cardiothoracic surgery prior to referral to our unit. A combined otolaryngology and plastic surgery approach was agreed. Division of omohyoid enabled access to the mass (figure 2), which was found to lie deep to the brachial plexus, except for the suprascapular nerve, 
which lay anterior. Muscular fibres of middle scalene and levator scapulae enveloped the mass and were therefore divided, as was the thoracic duct.

Intravascular papillary endothelial hyperplasia (IPEH) is a benign vascular lesion, ${ }^{1}$ accounting for $2 \%$ of soft tissue and skin vascular tumours. ${ }^{2}$ Similarities in clinical, radiological and histopathological features make it important to distinguish IPEH from angiosarcoma, to avoid misdiagnosis and subsequent overly aggressive surgical and systemic management of IPEH. ${ }^{3}$ Although other cases of IPEH presenting as a lateral neck mass exist, ${ }^{4-6}$ our case is unusual with regards to its location in the supraclavicular fossa. ${ }^{457}$ This, combined with its size, extension into the thoracic cavity and proximity to the brachial plexus, posed a unique challenge to surgical excision requiring MDT input, ${ }^{47}$ not previously reported. ${ }^{6}$

\section{Learning points}

- Although rare, intravascular papillary endothelial hyperplasia should be included as a differential diagnosis in a supraclavicular fossa lump.

- Location of lesions in the supraclavicular fossa can complicate and delay surgical management due to an overlap in surgical territories.

- Early multidisciplinary team involvement for lumps in the supraclavicular fossa is therefore indicated to minimise delays in definitive patient management.
This case therefore not only describes an unusual location of IPEH, but also highlights the difficulties associated with initial and definitive management of IPEH when located in the supraclavicular fossa, including the need for an MDT approach.

Contributors $\operatorname{Dr}$ CS was the main author of the case report. Dr SS contributed to the content of the article. Mr JG contributed to the editing and review of the case report.

Funding The authors have not declared a specific grant for this research from any funding agency in the public, commercial or not-for-profit sectors.

Competing interests None declared.

Patient consent for publication Obtained.

Provenance and peer review Not commissioned; externally peer reviewed.

\section{ORCID iD}

Catriona Shenton http://orcid.org/0000-0001-9894-6248

\section{REFERENCES}

1 Clearkin KP, Enzinger FM. Intravascular papillary endothelial hyperplasia. Arch Pathol Lab Med 1976;100:441-4.

2 Amérigo J, Berry CL. Intravascular papillary endothelial hyperplasia in the skin and subcutaneous tissue. Virchows Arch A Pathol Anat Histol 1980;387:81-90.

3 D'Aguanno V, Ralli M, De Virgilio A, et al. The role of differential diagnosis in intravascular papillary endothelial hyperplasia of the sinonasal cavity mimicking angiosarcoma: a case report. Oncol Lett 2019;17:1253-6.

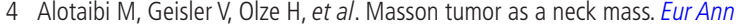
Otorhinolaryngol Head Neck Dis 2020;137:217-8.

5 Pantanowitz L, Muc R, Spanger M, et al. Intravascular papillary endothelial hyperplasia (Masson's tumor) manifesting as a lateral neck mass. Ear Nose Throat J 2000;79:806-15.

6 Yücesoy C, Coban G, Yilmazer D, et al. Intravascular papillary endothelial hyperplasia (Masson's hemangioma) presenting as a lateral neck mass. JBR-BTR 2009;92:20-2.

7 Lohia S, Momin S, Richardson MS, et al. Intravascular papillary endothelial hyperplasia of the neck: a case report. ОTO Open 2017;1:2473974X1769979.

Copyright 2021 BMJ Publishing Group. All rights reserved. For permission to reuse any of this content visit

https://www.bmj.com/company/products-services/rights-and-licensing/permissions/

BMJ Case Report Fellows may re-use this article for personal use and teaching without any further permission.

Become a Fellow of BMJ Case Reports today and you can:

- Submit as many cases as you like

- Enjoy fast sympathetic peer review and rapid publication of accepted articles

- Access all the published articles

- Re-use any of the published material for personal use and teaching without further permission

Customer Service

If you have any further queries about your subscription, please contact our customer services team on +44 (0) 2071111105 or via email at support@bmj.com.

Visit casereports.bmj.com for more articles like this and to become a Fellow 